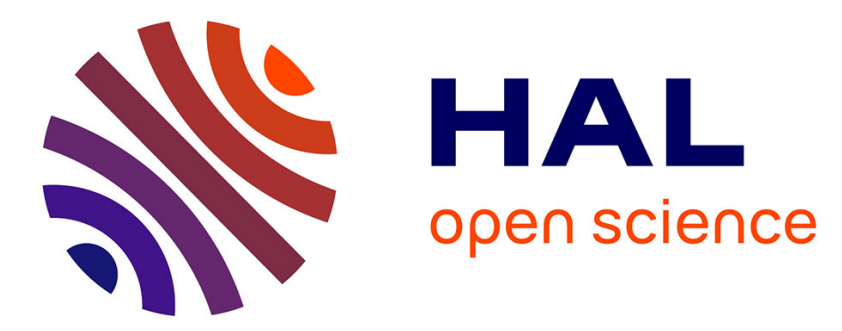

\title{
Synthesis of a perylenediimide-fullerene C60 dyad: A simple use of a nitro leaving group for a Suzuki-Miyaura coupling reaction
}

\author{
Rayane El-Berjawi, Piétrick Hudhomme
}

\section{- To cite this version:}

Rayane El-Berjawi, Piétrick Hudhomme. Synthesis of a perylenediimide-fullerene C60 dyad: A simple use of a nitro leaving group for a Suzuki-Miyaura coupling reaction. Dyes and Pigments, 2018, 159, pp.551-556. 10.1016/j.dyepig.2018.07.037 . hal-02564567

\section{HAL Id: hal-02564567 \\ https://univ-angers.hal.science/hal-02564567}

Submitted on 17 Jun 2021

HAL is a multi-disciplinary open access archive for the deposit and dissemination of scientific research documents, whether they are published or not. The documents may come from teaching and research institutions in France or abroad, or from public or private research centers.
L'archive ouverte pluridisciplinaire HAL, est destinée au dépôt et à la diffusion de documents scientifiques de niveau recherche, publiés ou non, émanant des établissements d'enseignement et de recherche français ou étrangers, des laboratoires publics ou privés.

\section{(c)(1)}

Distributed under a Creative Commons Attribution| 4.0 International License 


\title{
Synthesis of a perylenediimide-fullerene $C_{60}$ dyad: A simple use of a nitro leaving group for a Suzuki-Miyaura coupling reaction
}

\author{
Rayane El-Berjawi and Piétrick Hudhomme*
}

Université d'Angers, CNRS UMR 6200, Laboratoire MOLTECH-Anjou, 2 Bd Lavoisier, 49045 Angers cedex, France.

E-mail: pietrick.hudhomme@univ-angers.fr

Keywords: Perylenediimide / Fullerene / Donor-Acceptor / Suzuki-Miyaura / Nitro group

\begin{abstract}
We describe herein a straightforward synthesis of a fullerene $C_{60}$ - perylenediimide $\left(\mathrm{C}_{60^{-}}\right.$ PDI) dyad. A simple and original cross-coupling Suzuki-Miyaura reaction was carried out using mononitro-bay substituted PDI as an electron-deficient aromatic system playing the role of electrophilic partner. Optical and electrochemical characterizations of this $\mathrm{C}_{60}$-PDI dyad are also reported.
\end{abstract}

\section{Introduction}

Thanks to their exceptional high chemical, thermal and photochemical stability, perylenediimide (PDI) derivatives $\mathbf{1}$ are used as dyes and pigments [1,2]. With additional photophysical and photochemical properties characterized by high quantum yields of photoluminescence, PDI derivatives present potential applications as fluorescent dyes [3], near-IR dyes [4], molecular switches [5], dye lasers [6] and for water-soluble chromophores, the exploitation of their biocompatibility [7]. Moreover, their high electron affinity makes PDI derivatives strong electron acceptors with low lying LUMOs for utilization in organic electronics [8]. Additional interesting charge carrier mobilities [9] provide large prospects of these materials for investigations in organic solar cells [10-13]. Particularly, in order to take advantage of the solar spectrum coverage of the dye, intensive efforts have been devoted towards the synthesis of $\mathrm{C}_{60}$-PDI dyads in the search of photoinduced electron and/or energy transfer processes. In most of the described examples, fullerene $\mathrm{C}_{60}$ was attached at the imide position of the PDI [14-20] and these interesting super-absorbing fullerenes [21,22] could be used in organic solar cells [23]. Some other light-harvesting PDI-C ${ }_{60}$ dyads were prepared as organic triplet photosensitizers with potential applications in photocatalysis, photooxidation and photodynamic therapy [24,25]. In a few examples, $\mathrm{C}_{60}$ unit has been linked at the bay region of the PDI core [26-28]. Dyad systems 1a [18] and 1b [24] were synthesized starting from mono-bromoPDI derivative conveniently substituted at the imide position. The creation of a carbon-carbon bond is highly essential in organic chemistry for synthesizing more and more sophisticated molecules. Palladium-catalyzed coupling reactions are among the most popular and versatile carbon-carbon bond formation methods involving aromatic systems. 
Usually, these reactions known as Heck, Suzuki-Miyaura, Negishi, Stille, Sonogashira reactions, depending on the hybridization of the carbon atom, are conventionally employing aryl halides as electrophilic coupling partners. Considering the Suzuki-Miyaura coupling (SMC), aromatic boron derivatives are playing the role of nucleophilic coupling partners. Very recently, the first Pd-catalyzed Suzuki-Miyaura reaction using nitroarene with the nitro group acting as the leaving group was reported [29]. Nevertheless, this new reaction was demonstrated using only nitrobenzene derivatives substituted with electron-donating groups. On the other hand, monohalogenation in the PDI series is considered as a difficult reaction to control because of the easy access to dibromo derivative. Moreover, the advantage of the nitro group results in an interesting better atom economy process. Consequently, we were interested in the investigation of the SMC applied in the PDI series using the nitro group as the electrophilic coupling partner. Herein we describe the synthesis of a PDI-C 60 dyad using as an intermediate reaction, an efficient and easy SMC from mono-nitroPDI as an electron poor aromatic starting material.

\section{Results and discussion}

\subsection{Synthesis}

N.R. Champness and coll. reported the synthesis and electrochemical studies of dyad $\mathbf{1 a}$. Starting from mono-bromoPDI 3a, a SMC using 4-formylphenyl boronic acid in the presence of $\mathrm{CsF}, \mathrm{Ag}_{2} \mathrm{O}, \mathrm{Pd}\left(\mathrm{PPh}_{3}\right)_{4}$ in THF yielded compound 4a in $78 \%$ yield (Scheme 1). Further Prato reaction using $\mathrm{C}_{60}$ and $N$-ethylglycine in refluxing toluene afforded dyad 1a in $42 \%$ yield. J. Zhao and coll. described the synthesis of dyad $\mathbf{1 b}$ and its detailed photophysical properties. Starting material $\mathbf{2 b}$ was obtained in $77 \%$ yield by imidization reaction of perylene-3,4:9,10-tetracarboxylic acid dianhydride (PTCDA). Bromination of compound $2 \mathbf{b}$ using $\mathrm{Br}_{2}$ in $\mathrm{CHCl}_{3}$ at room temperature gave corresponding PDI $3 \mathbf{b}$ in $22 \%$ yield. The $\mathrm{SMC}$ was carried out using 4-formylphenyl boronic acid in the presence of $\mathrm{Na}_{2} \mathrm{CO}_{3}, \mathrm{Pd}\left(\mathrm{PPh}_{3}\right)_{4}$ in 2 methoxyethanol and water yielding compound $\mathbf{4 b}$ in $72 \%$ yield. A modified Prato reaction using creatine and $\mathrm{C}_{60}$ in refluxing toluene afforded dyad $\mathbf{1 b}$ in lower $12 \%$ yield.

Concerning the bromination reaction, the low reactivity of PDI towards electrophiles was first demonstrated by $\mathrm{H}$. Langhals and coll. Moreover, this bromination reaction suffers from its lack of selectivity with the concomitant introduction of a second bromine atom yielding to a mixture of 1,6- and 1,7-dibrominated PDI [31,32]. Compound 3c with $N, N$ '-dicyclohexyl groups was shown to be not accessible while upon reflux in $\mathrm{CH}_{2} \mathrm{Cl}_{2}$ for 4 days and only the mixture of 1,6- and 1,7-dibrominated regioisomers was obtained [32]. Very recently, PDI derivative 3c was used as a starting material but its preparation was not described [33]. 


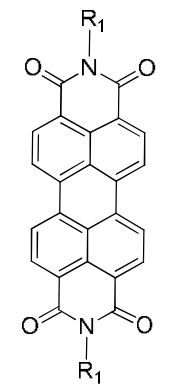

2

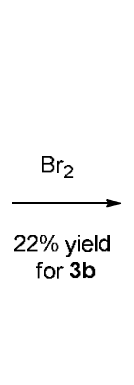

$\left.\mathrm{CH}_{2}\right)_{3}$

2a: $\mathrm{R}_{1}=\mathrm{CH}_{3}\left(\mathrm{CH}_{2}\right)_{3}$

2b : $\mathrm{R}_{1}=\mathrm{CH}_{3}\left(\mathrm{CH}_{2}\right)_{3} \mathrm{CH}\left(\mathrm{C}_{2} \mathrm{H}_{5}\right) \mathrm{CH}_{2}$

2c : $\mathrm{R}_{1}=\mathrm{C}_{6} \mathrm{H}_{11}$

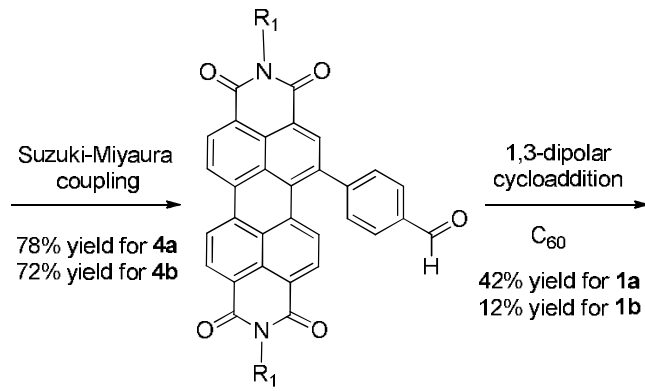

4

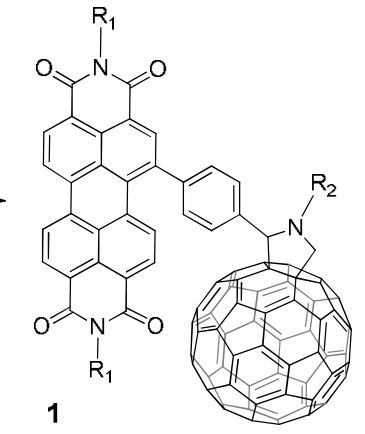

1a: $\mathrm{R}_{1}=\mathrm{CH}_{3}\left(\mathrm{CH}_{2}\right)_{3}-\mathrm{R}_{2}=\mathrm{CH}_{3} \mathrm{CH}_{2}$ 1b: $\mathrm{R}_{1}=\mathrm{CH}_{3}\left(\mathrm{CH}_{2}\right)_{3} \mathrm{CH}\left(\mathrm{C}_{2} \mathrm{H}_{5}\right) \mathrm{CH}_{2} ; \mathrm{R}_{2}=\mathrm{CH}_{3}$

Scheme 1. Reported synthesis of dyads 1a-b.

From all these considerations, we were interested in the access to mononitrated PDI derivative 5 and its potential use in the SMC reaction to reach target dyad 7 (Scheme 2). The mononitration reaction was effectively expected to be easier to control rather than monobromination, thanks to the inductive and mesomeric electron-withdrawing effects of the nitro group which sufficiently deactivates the PDI core towards the second electrophilic substitution. First, starting material PTCDA was transformed in 98\% yield into compound 2c by an imidization reaction using cyclohexylamine in refluxing DMF as a simplified and modified procedure than those reported [34-36]. Concerning the nitration reaction, we were not able to realize the nitration of compound $2 \mathrm{c}$ by using $\mathrm{HNO}_{3} 0.1 \mathrm{M}$ in the presence of cerium ammonium nitrate (CAN) as described [37]. On the contrary, we have shown that the nitration reaction could be done using fuming nitric acid where the addition of CAN was not improving the yield or favoring the kinetic of the reaction [38]. We have succeeded in preparing mono-nitroPDI 5 in $93 \%$ yield (at room temperature and in short time) in a multigram scale without the need of purification using chromatographic techniques as a new simplified procedure [39].

The SMC was investigated using 3-formylphenylboronic acid instead of the reported synthesis of dyad 1 realized with 4-formylphenylboronic acid. We have previously shown on PMI- $\mathrm{C}_{60}$ dyads that the shortest distance between the perylene core and $\mathrm{C}_{60}$ was in agreement with the ortho, meta, or para substitution of the phenyl group [40]. The described and optimized conditions for the SMC of nitroarenes with arylboronic acids were using $\mathrm{Pd}(\mathrm{acac})_{2}$, BrettPhos, 18-crown-6 and $\mathrm{K}_{3} \mathrm{PO}_{4} \cdot \mathrm{nH}_{2} \mathrm{O}$ in 1,4-dioxane at $130{ }^{\circ} \mathrm{C}$ for $24 \mathrm{~h}$. The absence of 18-crown-6 in the reaction medium resulted in a slightly decreased yield, $\mathrm{Pd}\left(\mathrm{PPh}_{3}\right)_{4}$ was found to be not effective and using toluene or THF as a solvent resulted in a diminished yield. Concerning the impact of the base, while $\mathrm{CsF}$ afforded the targeted biaryl compound, $\mathrm{Cs}_{2} \mathrm{CO}_{3}$ and $\mathrm{K}_{2} \mathrm{CO}_{3}$ did not, and the water contamination in $\mathrm{K}_{3} \mathrm{PO}_{4}$ seemed important [29]. We present herein a straightforward and simplified procedure using 3-formylphenylboronic acid in the presence only of $\mathrm{Pd}\left(\mathrm{PPh}_{3}\right)_{4}$ and $\mathrm{K}_{3} \mathrm{PO}_{4}$ as a base in refluxing THF. Compound 6 was isolated in a satisfactory $81 \%$ yield after column chromatography and crystallization. This reaction corresponds to the first example of SMC reaction using an electron-deficient arene system such as PDI possessing a nitro group as the electrophilic coupling partner. To the best of our 
knowledge, mononitrated PDI was only known to react by replacement reactions using different nucleophiles known as aromatic nucleophilic substitutions [41]. Single crystals were obtained by slow evaporation of a solution containing PDI 6 in a mixture of $\mathrm{CHCl}_{3}$ and petroleum ether then analyzed by X-ray diffraction. The crystallographic analysis revealed that the central six-membered ring is slightly twisted with a torsion angle of $11.74(4)^{\circ}$ associated with bay carbons C7-C8-C13-C22 and C9-C10-C15-C14, respectively (Fig. 1). On the other hand, the deviation of the phenyl group with respect to the PDI core is equal to $61.03(9)^{\circ}$.<smiles>O=C1OC(=O)c2ccc3c4ccc5c6c(ccc(c7ccc1c2c73)c64)C(=O)OC5=O</smiles><smiles>NC1CCCCC1</smiles>
$98 \%$ yield PTCDA<smiles></smiles>

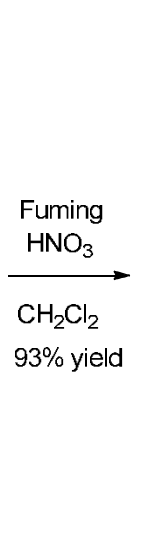

2c
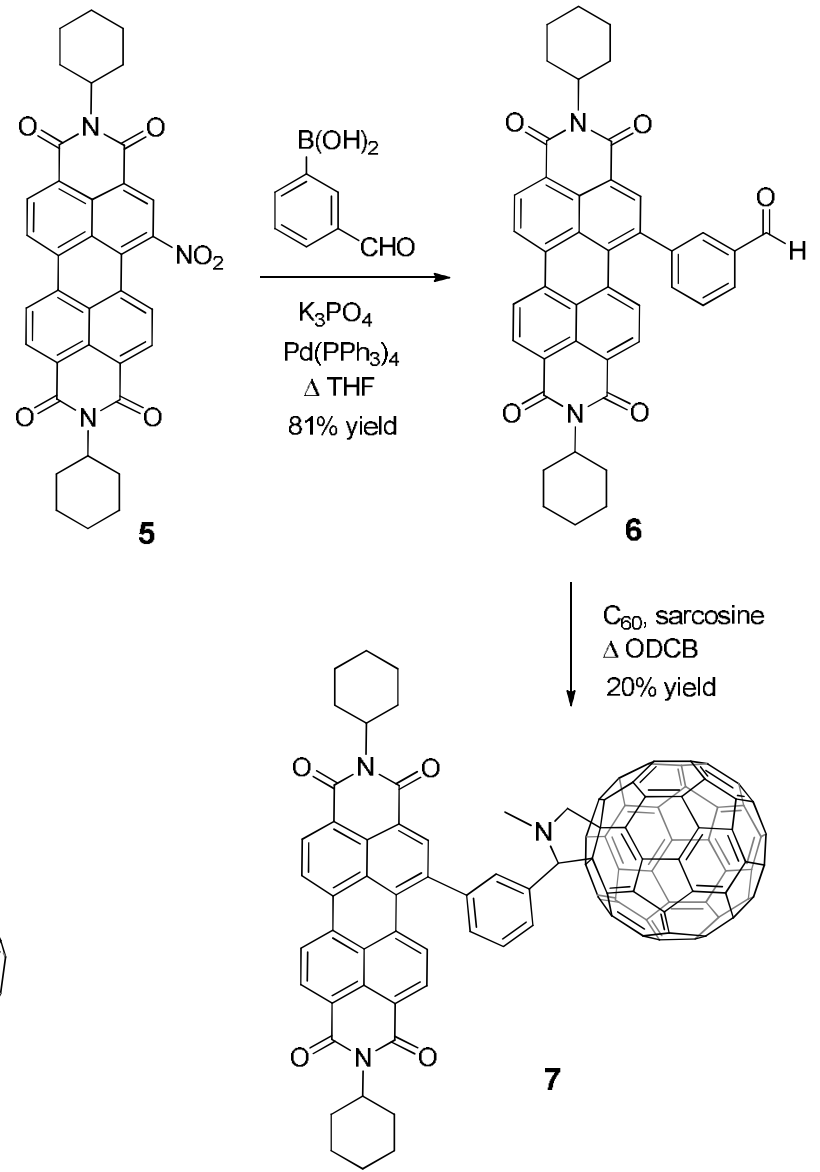

Scheme 2. Suzuki-Miyaura coupling reaction from nitroPDI and synthesis of dyad PDI-C 60.

Considering that in compound $\mathbf{6}$ the formyl group in meta position presents only an electronwithdrawing inductive effect, we have investigated the extension of this SMC reaction using a phenyl boronic acid substituted in para position either by an electron-withdrawing group or -donating group by mesomeric effect. Reaction with (4-formylphenyl)boronic acid or [(4diphenylamino)phenyl]boronic acid [42] led to compound $\mathbf{4 c}$ and $\mathbf{9}$ in $85 \%$ and $75 \%$ yield, respectively (Scheme 3). PDI derivative 9 was previously synthesized in $49 \%$ yield using SMC reaction from mono-bromoPDI 3c [43].This demonstrates the versatility of this original SMC reaction which could be used with varied substituted phenyl boronic acid derivatives. 

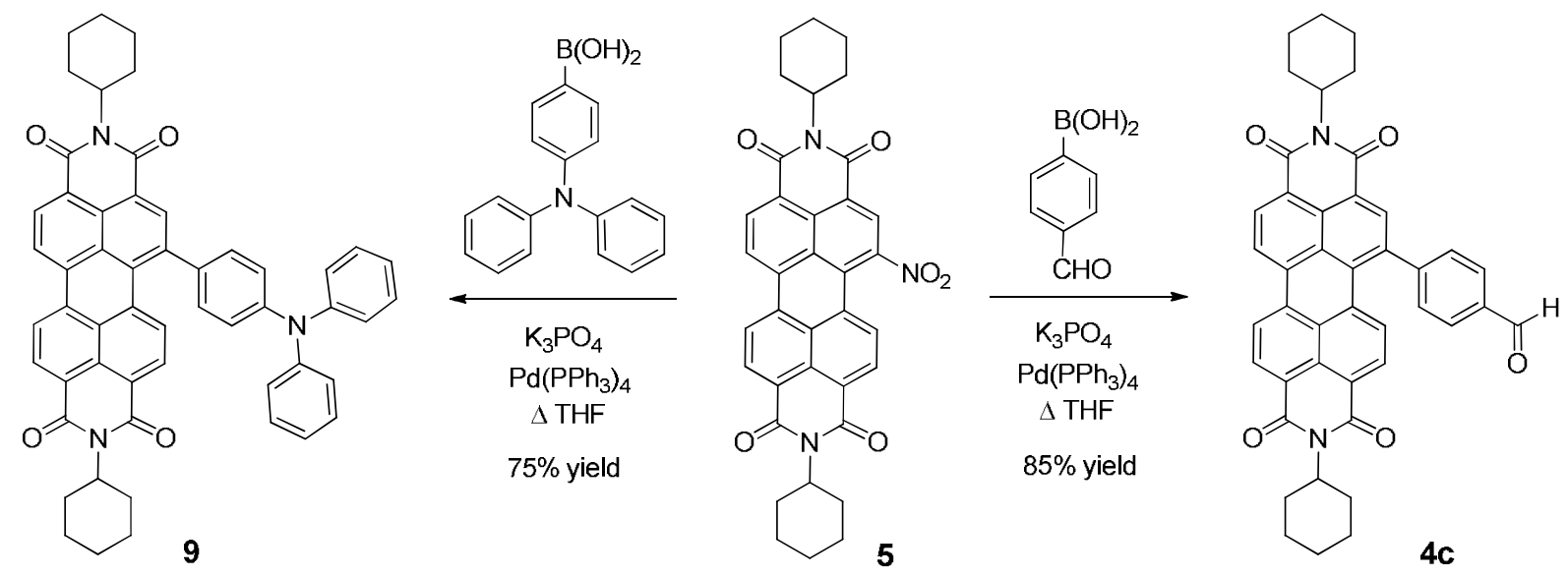

Scheme 3. Suzuki-Miyaura coupling reaction from nitroPDI using phenyl boronic acid substituted by electron-withdrawing or -donating group in para position.

Starting from compound 6, the subsequent 1,3-dipolar cycloaddition [44] was carried out using $\mathrm{C}_{60}$ and $\mathrm{N}$-methylglycine (sarcosine) in $o$-dichlorobenzene (o-DCB) at $180{ }^{\circ} \mathrm{C}$ affording, after purification by silica gel column chromatography, dyad 7 in $20 \%$ yield. The structure of PDI- $\mathrm{C}_{60}$ dyad 7 has been fully characterized through ${ }^{1} \mathrm{H}$ and ${ }^{13} \mathrm{C}$ NMR, mass spectrometry (MALDI-TOF and HRMS), and HPLC chromatography. From this technique, the purity of dyad 7 could be estimated to be higher to $99.8 \%$. As a further reference for electrochemical and optical studies, fulleropyrrolidine $\mathbf{8}$ was prepared using benzaldehyde as the starting material to generate the azomethine ylide.
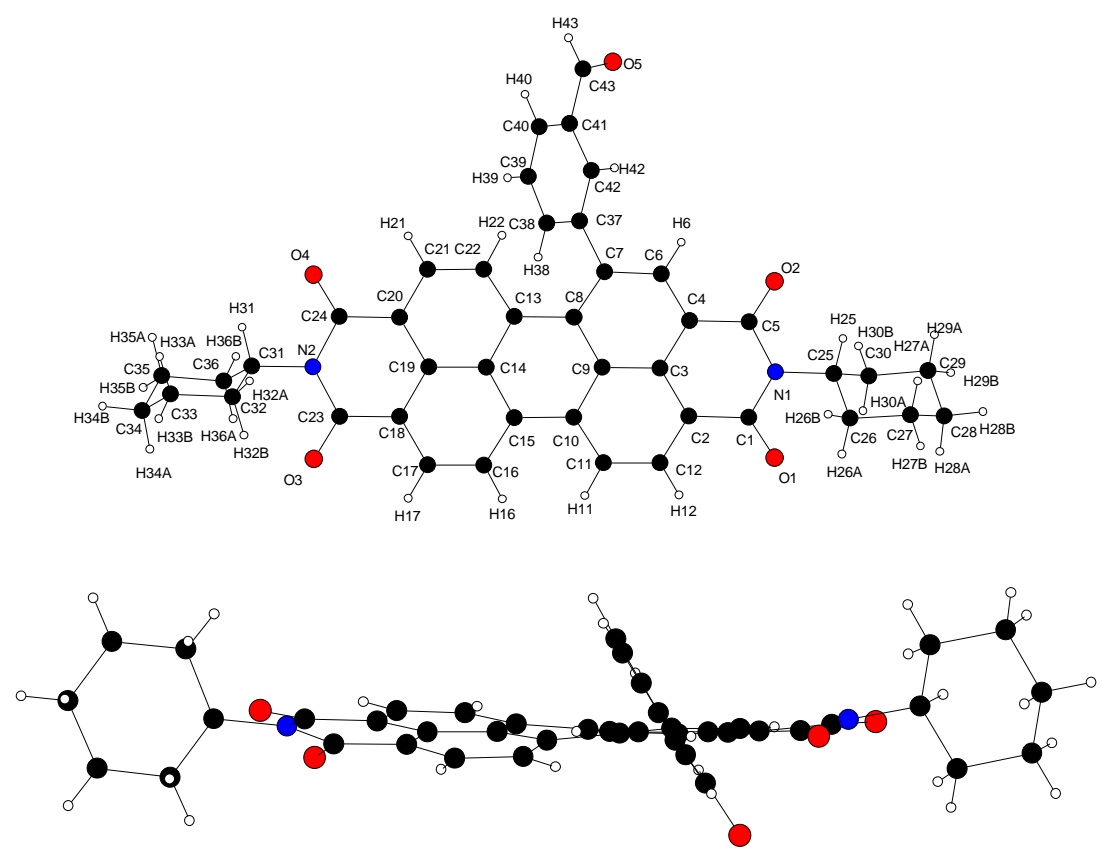

Fig. 1. View of the crystal structure of PDI derivative 6 (top) for determining the twist and distortion angles (down). 


\subsection{Electrochemical and optical properties}

The electrochemical properties of PDI derivatives $\mathbf{5}$ and $\mathbf{6}$, dyad $\mathbf{7}$ were investigated by cyclic voltammetry in $\mathrm{CH}_{2} \mathrm{Cl}_{2}$ in the presence of $\mathrm{Bu}_{4} \mathrm{NPF}_{6}$ as supporting electrolyte. While PDI derivatives show the expected two reversible one-electron reduction waves, we could detect four reversible reduction processes for dyad 7 (Fig. 2). Thanks to the deconvoluated cyclic voltammogram $(\mathrm{CV})$ of dyad 7 and comparison with voltammograms of PDI 6 and reference $\mathrm{C}_{60}$ derivative 8, we could assign the first wave to a two-electron process at $E_{\text {red }}^{1}=-1.05 \mathrm{~V}$ $v s \mathrm{Fc} / \mathrm{Fc}^{+}$, suggesting that the first reduction process of $\mathrm{C}_{60}$ and the first reduction process of PDI are overlapping. Consequently this process was assigned to a simultaneous reduction of $\mathrm{C}_{60}$ and PDI leading to dianion-diradical $\mathrm{C}_{60}{ }^{-}-\mathrm{PDI}^{-}$species. The second $\left(E_{\text {red }}^{2}=-1.23 \mathrm{~V}\right)$, third $\left(E_{\text {red }}^{3}=-1.46 \mathrm{~V}\right)$ and fourth $\left(E_{\text {red }}^{4}=-1.99 \mathrm{~V}\right)$ waves were assigned to one-electron processes corresponding to the successive formation of $\mathrm{C}_{60}{ }^{-}-\mathrm{PDI}^{2-}$, then $\mathrm{C}_{60}{ }^{2-}-\mathrm{PDI}^{2-}$, and at the end $\mathrm{C}_{60}{ }^{3 .-}-\mathrm{PDI}^{2-}$ species (Table 1). Moreover, comparison of these different values for dyad 7 with reference compounds $\mathbf{6}$ and $\mathbf{8}$ suggests that there is no significant interaction taking place between both electroactive moieties in the ground state.
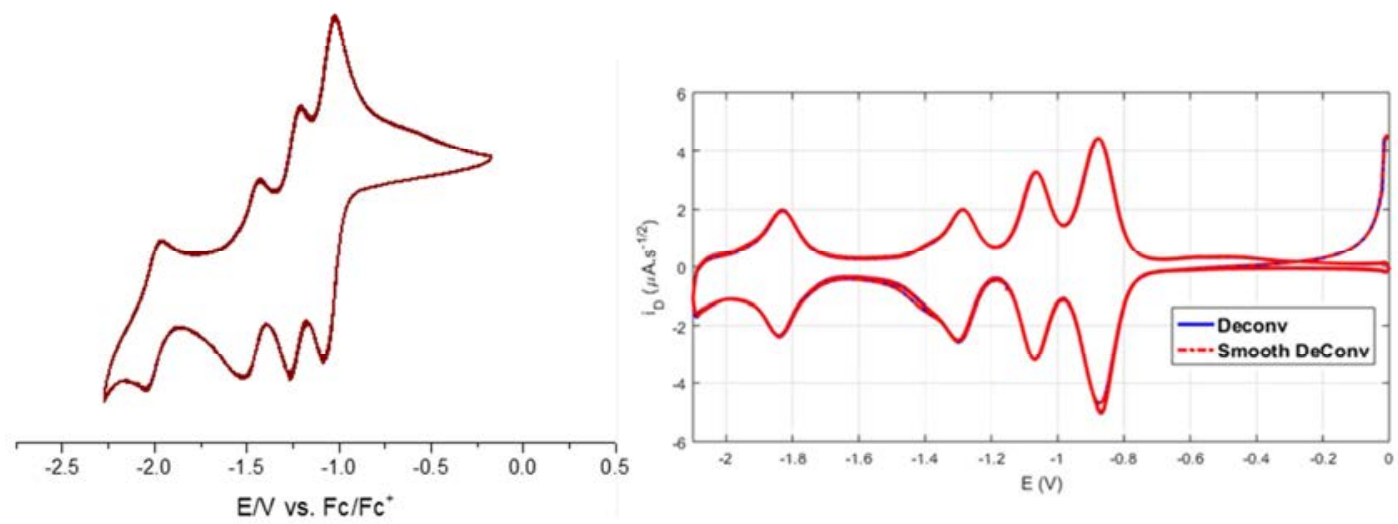

Fig. 2. Cyclic voltammogram (CV) and deconvoluted CV of PDI-C 60 dyad 7.

Table 1. Redox potential values $\left(\mathrm{V} v s \mathrm{Fc}^{+} / \mathrm{Fc}\right.$ ) of $\mathrm{PDI}-\mathrm{C}_{60}$ dyad $\mathbf{7}$ and reference compounds $\mathbf{5}$, 6 and 8. Values recorded in a $\mathrm{CH}_{2} \mathrm{Cl}_{2}$ solution $(0.5 \mathrm{mM})$ for $\mathbf{5}, 6$ and 7 and $o-\mathrm{DCB} / \mathrm{CH}_{2} \mathrm{Cl}_{2}$ (1:1.2) for 8 , using $\mathrm{Bu}_{4} \mathrm{NPF}_{6} 0.1 \mathrm{M}$ as the supporting electrolyte, platinum wires as counter and working electrodes. Scan rate: $100 \mathrm{mV} / \mathrm{s}$.

\begin{tabular}{ccccc}
\hline Compound & $\mathrm{E}_{\text {red }}^{1}$ & $\mathrm{E}_{\text {red }}^{2}$ & $\mathrm{E}_{\text {red }}^{3}$ & $\mathrm{E}_{\text {red }}^{4}$ \\
\hline $\mathbf{5}$ & -0.77 & -0.98 & & \\
$\mathbf{6}$ & -0.98 & -1.17 & & \\
$\mathbf{7}$ & -1.05 & -1.23 & -1.46 & -1.99 \\
$\mathbf{8}$ & -1.07 & -1.44 & -1.97 & \\
\hline
\end{tabular}


The optical properties of dyad $\mathbf{7}$ and PDI derivatives $\mathbf{5}$ and $\mathbf{6}$ have been analyzed in diluted $\mathrm{CH}_{2} \mathrm{Cl}_{2}$ solutions by UV-vis absorption $\left(\mathrm{ca} .10^{-5} \mathrm{M}\right.$ ) and photoluminescence emission ( $\mathrm{ca}$. 10$\left.{ }^{6} \mathrm{M}\right)$ spectroscopy (Fig. 3). Absorption and steady-state fluorescence emissions of PDI derivatives 5 and $\mathbf{6}$, dyad $\mathbf{7}$ in $\mathrm{CH}_{2} \mathrm{Cl}_{2}$ are collected in table 2. The UV-vis spectrum of these three compounds is characterized by two main absorption bands with a first peak with a maximum $\left(\lambda_{\max }\right)$ at $520-530 \mathrm{~nm}$ and a shoulder $(490-500 \mathrm{~nm})$ which corresponds to $S_{0} \rightarrow S_{1}$ transition of PDI oriented along the long axis. A second peak $(440-450 \mathrm{~nm})$ is attributed to the $S_{0} \rightarrow S_{2}$ transition oriented perpendicular to the long axis [45]. To summarize, the UV-vis spectrum of PDI- $\mathrm{C}_{60}$ dyad 7 corresponds to the superimposition of the optical signature of PDI with that of $\mathrm{C}_{60}$ derivative suggesting the absence of electronic coupling in the ground state between the acceptor PDI and the fullerene moiety.

These results are in agreement with the electrochemical studies of dyad 1a reported by N.R. Champness and coll.[18] In the case of dyad 1a, an overlap of the first reduction potentials and PDI moieties was observed confirming that the initial reduction step was leading to the simultaneous formation of the $\mathrm{C}_{60}{ }^{-}-\mathrm{PDI}^{-}$species. It was also demonstrated by complementary spectroelectrochemical studies that this two-electron step was followed by two one-electron processes leading to the successive formation of $\mathrm{C}_{60}{ }^{--}-\mathrm{PDI}^{2-}$, then $\mathrm{C}_{60}{ }^{2-}-$ $\mathrm{PDI}^{2-}$ species.

Table 2. UV-vis absorption $\left(10^{-5} \mathrm{M}\right.$ in $\left.\mathrm{CH}_{2} \mathrm{Cl}_{2}\right)$ and emission data $\left(10^{-6} \mathrm{M}^{-} \mathrm{CH}_{2} \mathrm{Cl}_{2}\right)$ of PDI derivatives 5, $\mathbf{6}$ and dyad $\mathbf{7 .}$

\begin{tabular}{ccccccccc}
\hline Compound & $\begin{array}{c}\lambda_{1} \\
(\mathrm{~nm})\end{array}$ & $\begin{array}{c}\varepsilon_{1} \\
\left(\mathrm{M}^{-1} \mathrm{~cm}^{-1}\right)\end{array}$ & $\begin{array}{c}\lambda_{2} \\
(\mathrm{~nm})\end{array}$ & $\begin{array}{c}\varepsilon_{2} \\
\left(\mathrm{M}^{-1} \mathrm{~cm}^{-1}\right)\end{array}$ & $\Phi^{\mathrm{a}}$ & $\mathrm{E}_{\mathrm{g}}^{\mathrm{b}}$ & $\begin{array}{c}\mathrm{E}^{\text {LUMO }} \\
(\mathrm{eV})^{\mathrm{c}}\end{array}$ & $\begin{array}{c}\mathrm{E}^{\text {HOMO }} \\
(\mathrm{eV})^{\mathrm{d}}\end{array}$ \\
\hline $\mathbf{5}$ & 488 & 30900 & 521 & 46100 & 0 & 2.19 & -4.33 & -6.52 \\
$\mathbf{6}$ & 496 & 31400 & 530 & 45400 & $0.66^{\mathrm{e}}$ & 2.27 & -4.11 & -6.38 \\
$\mathbf{7}$ & 497 & 28900 & 533 & 41200 & 0.01 & 2.16 & -4.05 & -6.21 \\
\hline
\end{tabular}

${ }^{\text {a }} N, N$ '-diphenylperylenediimide $\left(\Phi_{\mathrm{f}}=0.96\right.$ in $\left.\mathrm{CH}_{3} \mathrm{CN}\right)$ was used as standard for fluorescence quantum yield measurements [46]. The excitation wavelength was set at $530 \mathrm{~nm}$.

${ }^{\mathrm{b}}$ Determined at the intersection of the absorption and emission spectra normalized with respect to the lowest energy absorption and from the onset of absorption.

${ }^{\mathrm{c}}$ Energy of the Lowest Unoccupied Molecular Orbital $\mathrm{E}^{\mathrm{LUMO}}$ in $\mathrm{eV}$ determined from $\mathrm{E}^{\mathrm{LUMO}}=-\left(\mathrm{E}_{\text {red }}^{1}+\right.$ 5.1).

${ }^{\mathrm{d}}$ Energy of the Highest Occupied Molecular Orbital determined from $\mathrm{E}^{\mathrm{HOMO}}=\left[\mathrm{E}_{\mathrm{LumO}}-\mathrm{E}_{\mathrm{g}}\right]$. Values of 4.25 and -6.64 for LUMO and HOMO, respectively, have been previously reported [37].

${ }^{\mathrm{e}} \lambda_{\mathrm{em}}=566 \mathrm{~nm}$

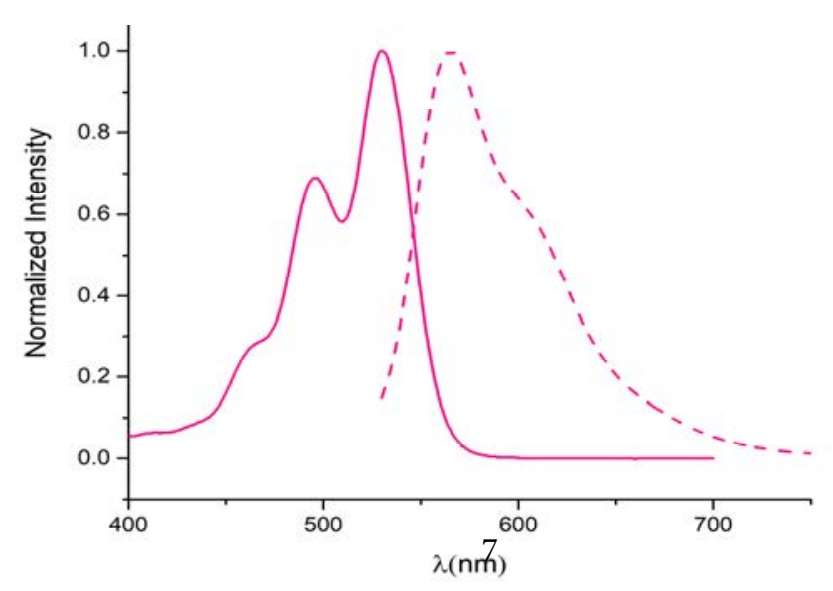


Fig. 3. Normalized steady-state absorption (full line) and emission spectra (dotted line; $\lambda_{\mathrm{ex}}=$ $530 \mathrm{~nm}$ ) of compound 6 in $\mathrm{CH}_{2} \mathrm{Cl}_{2}$.

In agreement with reported data [41], mono-nitroPDI derivative 5 does not exhibit any emission. On the other hand, in comparison with fluorescence spectrum of PDI 6, a quasiquantitative quenching ( $\mathrm{ca} .98 .5 \%$ ) of the PDI fluorescence emission was observed in dyad 7 (Table 2). This fluorescence quantum yield decrease suggested the occurrence of either a photo-induced electron transfer or an energy transfer in solution from the photo-excited PDI chromophore to the electron-accepting fullerene unit.

Such photophysical properties were studied in detail by J. Zhao and coll. for dyad 1b. [24] In the case of dyad 1b, an estimated $98 \%$ quenching of fluorescence was observed. This was attributed to an intramolecular energy transfer and nanosecond time-resolved transient absorption and spin density analyses confirmed that the triplet state of dyad $\mathbf{1 b}$ is localized on the PDI unit. Moreover, dyad $\mathbf{1 b}$ was used as a singlet oxygen photosensitizer for photooxidation of 1,5-dihydroxynaphthalene and such $\mathrm{C}_{60}$-PDI dyads present potential models to be used in photodynamic therapy. In another field of applications, considering their higher absorption in the visible range, light-harvesting fullerene derivatives could be used in organic solar cells by replacing advantageously PCBM [47] or in ternary blends [48].

\section{Conclusion}

In conclusion, we have developed a straightforward methodology to realize a Suzuki-Miyaura coupling (SMC) reaction using an electron-deficient arene system possessing a nitro group as the electrophilic coupling partner. We adopted this reaction to construct a PDI- $\mathrm{C}_{60}$ dyad for which $\mathrm{C}_{60}$ is connected at the bay region of the PDI core. Applications as singlet-oxygen photosensitizers and incorporation in organic solar cells of this visible light-harvesting PDI$\mathrm{C}_{60}$ dyad are currently underway. We believe that this SMC reaction from nitro arene could provide guidance to be applied for the design and synthesis of new aromatic systems useful for organic electronics.

\section{Acknowledgements}

Angers Loire Métropole (ALM) and the University of Angers are acknowledged for a PhD grant to Rayane El-Berjawi (program RFI Lumomat). The authors acknowledge the PIAM (Plateforme d'Ingénierie et Analyses Moléculaires) of the University of Angers with Sonia Jerjir and Dr Ingrid Freuze for their assistance in mass spectrometry experiments. Magali 
Allain for X-ray diffraction analysis, Dr Olivier Alévêque and Dr Eric Levillain for fruitful discussions concerning electrochemical experiments are also thanked.

\section{References}

[1] Langhals H. Cyclic carboxylic imide structures as structure elements of high stability. Novel developments in perylene dye chemistry. Heterocycles 1995;1:477-500.

[2] Würthner F. Perylene bisimide dyes as versatile building blocks for functional supramolecular architectures. Chem Commun 2004:1564-79.

[3] Soh N, Ueda T. Perylene bisimide as a versatile fluorescent tool for environmental and biological analysis: A review. Talanta 2011;85:1233-7.

[4] Quante H, Geerts Y, Müllen K. Synthesis of soluble perylenebisamidine derivatives. Novel long-wavelength absorbing and fluorescent dyes. Chem Mater 1997;9:495-500.

[5] Sánchez RS, Gras-Charles R, Bourdelande JL, Guirado G, Hernando J. Light- and Redox-Controlled Fluorescent Switch Based on a Perylenediimide-Dithienylethene Dyad. J Phys Chem C 2012;116:7164-72.

[6] Yu Z, Wu Y, Liao Q, Zhang H, Bai S, Li H, et al. Self-Assembled Microdisk Lasers of Perylenediimides. J Am Chem Soc 2015;137:15105-11.

[7] Sun M, Müllen K, Yin M. Water-soluble perylenediimides: design concepts and biological applications. Chem Soc Rev 2016;45:1513-28.

[8] Huang C, Barlow S, Marder SR. Perylene-3,4,9,10-tetracarboxylic Acid Diimides: Synthesis, Physical Properties, and Use in Organic Electronics. J Org Chem 2011;76:2386-407.

[9] Struijk CW, Sieval AB, Dakhorst JEJ, van Dijk M, Kimkes P, Koehorst RBM, et al. Liquid Crystalline Perylene Diimides: Architecture and Charge Carrier Mobilities. J Am Chem Soc 2000;122:11057-66.

[10] Anthony JE. Small-Molecule, Nonfullerene Acceptors for Polymer Bulk Heterojunction Organic Photovoltaics. Chem Mater 2011;23:583-90.

[11] Li C, Wonneberger H. Perylene Imides for Organic Photovoltaics: Yesterday, Today, and Tomorrow. Adv Mater 2012;24:613-36.

[12] Kozma E, Catellani M. Perylene diimides based materials for organic solar cells. Dyes Pigments 2013;98:160-79.

[13] Fernández-Lázaro F, Zink-Lorre N, Sastre-Santos Á. Perylenediimides as non-fullerene acceptors in bulk-heterojunction solar cells (BHJSCs). J Mater Chem A 2016;4:933646.

[14] Baffreau J, Perrin L, Leroy-Lhez S, Hudhomme P. Perylene-3,4:9,10-bis(dicarboximide) linked to [60]fullerene as a light-harvesting antenna. Tetrahedron Lett 2005;46:4599603.

[15] Gómez R, Segura JL, Martín N. Highly Efficient Light-Harvesting Organofullerenes. Org Lett 2005;7:717-20.

[16] Shibano Y, Umeyama T, Matano Y, Tkachenko NV, Lemmetyinen H, Imahori H. Synthesis and Photophysical Properties of Electron-Rich Perylenediimide-Fullerene Dyad. Org Lett 2006;8:4425-8.

[17] Hofmann CC, Lindner SM, Ruppert M, Hirsch A, Haque SA, Thelakkat M, et al. Mutual Interplay of Light Harvesting and Triplet Sensitizing in a Perylene Bisimide Antenna-Fullerene Dyad. J Phys Chem B 2010;114:9148-56.

[18] Chamberlain TW, Davies ES, Khlobystov AN, Champness NR. Multi $\square$ Electron $\square$ Acceptor Dyad and Triad Systems Based on Perylene Bisimides and Fullerenes. Chem Eur J 2011;17:3759-67. 
[19] Pla S, Martín-Gomis L, Ohkubo K, Fukuzumi S, Fernández-Lázaro F, Sastre-Santos Á. Macrocyclic Dyads Based on $\mathrm{C}_{60}$ and Perylenediimides Connected by Click Chemistry. Asian J Org Chem 2014;3:185-97.

[20] Hua J, Meng F, Ding F, Li F, Tian H. Novel soluble and thermally-stable fullerene dyad containing perylene. J Mater Chem 2004;14:1849.

[21] Baffreau J, Leroy-Lhez S, Hudhomme P, Groeneveld MM, van Stokkum IH, Williams RM. Superabsorbing fullerenes: spectral and kinetic characterization of photoinduced interactions in perylenediimide- fullerene-C60 dyads. J Phys Chem A 2006;110:1312313125.

[22] Baffreau J, Leroy-Lhez S, Vân Anh N, Williams RM, Hudhomme P. Fullerene C60Perylene-3,4:9,10-bis(dicarboximide) Light-Harvesting Dyads: Spacer-Length and BaySubstituent Effects on Intramolecular Singlet and Triplet Energy Transfer. Chem - Eur J 2008;14:4974-92..

[23] Baffreau J, Leroy-Lhez S, Derbal H, Inigo AR, Nunzi J-M, Groeneveld MM, et al. Light-harvesting fullerenes for organic solar cells. Eur Phys J - Appl Phys 2006;36:3015.

[24] Liu Y, Zhao J. Visible light-harvesting perylenebisimide-fullerene (C60) dyads with bidirectional "ping-pong" energy transfer as triplet photosensitizers for photooxidation of 1,5-dihydroxynaphthalene. Chem Commun 2012;48:3751.

[25] Zhu S-E, Liu K-Q, Wang X-F, Xia A-D, Wang G-W. Synthesis and Properties of Axially Symmetrical Rigid Visible Light-Harvesting Systems Containing [60]Fullerene and Perylenebisimide. J Org Chem 2016;81:12223-31.

[26] Kaunisto KM, Vivo P, Dubey RK, Chukharev VI, Efimov A, Tkachenko NV, et al. Charge-Transfer Dynamics in Poly(3-hexylthiophene):Perylenediimide-C 60 Blend Films Studied by Ultrafast Transient Absorption. J Phys Chem C 2014;118:10625-30.

[27] Pla S, Niemi M, Martín-Gomis L, Fernández-Lázaro F, Lemmetyinen H, Tkachenko $\mathrm{NV}$, et al. Charge separation and charge recombination photophysical studies in a series of perylene- $\mathrm{C}_{60}$ linear and cyclic dyads. Phys Chem Chem Phys 2016;18:3598-605.

[28] Li Y, Wang N, He X, Wang S, Liu H, Li Y, et al. Synthesis and characterization of ferrocene-perylenetetracarboxylic diimide-fullerene triad. Tetrahedron 2005;61:1563-9.

[29] Yadav MR, Nagaoka M, Kashihara M, Zhong R-L, Miyazaki T, Sakaki S, et al. The Suzuki-Miyaura Coupling of Nitroarenes. J Am Chem Soc 2017;139:9423-6.

[30] Langhals H, Kirner S. Novel Fluorescent Dyes by the Extension of the Core of Perylenetetracarboxylic Bisimides. Eur J Org Chem 2000;2000:365-80.

[31] Rajasingh P, Cohen R, Shirman E, Shimon LJW, Rybtchinski B. Selective Bromination of Perylene Diimides under Mild Conditions. J Org Chem 2007;72:5973-9.

[32] Dhokale B, Jadhav T, Patil Y, Misra R. Symmetrical and unsymmetrical ferrocenyl perylenediimides: Design, synthesis and properties. Dyes Pigments 2016;134:164-70.

[33] Cao L, Zhang D, Xu L, Fang Z, Jiang X-F, Lu F. Perylenediimide-Benzanthrone Dyad: Organic Chromophores with Enhanced Third-Order Nonlinear-Optical Activities. Eur J Org Chem 2017;2017:2495-500.

[34] Lin M-J, Jiménez ÁJ, Burschka C, Würthner F. Bay-substituted perylene bisimide dye with an undistorted planar scaffold and outstanding solid state fluorescence properties. Chem Commun 2012;48:12050.

[35] Jiménez ÁJ, Lin M-J, Burschka C, Becker J, Settels V, Engels B, et al. Structureproperty relationships for 1,7-diphenoxy-perylene bisimides in solution and in the solid state. Chem Sci 2014;5:608-19.

[36] Singh P, Kumar K, Bhargava G, Kumar S. Self-assembled nanorods of bay functionalized perylenediimide: $\mathrm{Cu}^{2+}$ based 'turn-on' response for $\mathrm{INH}$, complementary 
NOR/OR and TRANSFER logic functions and fluorosolvatochromism. J Mater Chem C 2016;4:2488-97.

[37] Chang C-W, Tsai H-Y, Chen K-Y. Green Perylene Bisimide Dyes: Synthesis, Photophysical and Electrochemical Properties. Materials 2014;7:5488-506.

[38] Chen K-Y, Fang T-C, Chang M-J. Synthesis, photophysical and electrochemical properties of 1-aminoperylene bisimides. Dyes Pigments 2012;92:517-23.

[39] Hendsbee AD, Sun J-P, Law WK, Yan H, Hill IG, Spasyuk DM, et al. Synthesis, SelfAssembly, and Solar Cell Performance of N-Annulated Perylene Diimide Non-Fullerene Acceptors. Chem Mater 2016;28:7098-109.

[40] Baffreau J, Ordronneau L, Leroy-Lhez S, Hudhomme P. Synthesis of Perylene-3,4mono(dicarboximide)-Fullerene $\mathrm{C}_{60}$ Dyads as New Light-Harvesting Systems. J Org Chem 2008;73:6142-7.

[41] Kong X, Gao J, Ma T, Wang M, Zhang A, Shi Z, et al. Facile synthesis and replacement reactions of mono-substituted perylene bisimide dyes. Dyes Pigments 2012;95:450-4.

[42] Wang H-Y, Shi J-J, Wang C, Zhang X-X, Wan Y, Wu H. Novel fluorescence dyes based on entirely new chromeno[4,3,2-de][1,6]naphthyridine framework. Dyes Pigments 2012;95:268-74.

[43] Cao L, Xu L, Zhang D, Zhou Y, Zheng Y, Fu Q, et al. D-A dyad and D-A-D triad incorporating triphenylamine, benzanthrone and perylene diimide: Synthesis, electrochemical, linear and nonlinear optical properties. Chem Phys Lett 2017;682:1339.

[44] Maggini M, Scorrano G, Prato M. Addition of azomethine ylides to C60: synthesis, characterization, and functionalization of fullerene pyrrolidines. $\mathrm{J}$ Am Chem Soc 1993;115:9798-9799.

[45] Fron E, Pilot R, Schweitzer G, Qu J, Herrmann A, Müllen K, et al. Photoinduced electron-transfer in perylenediimide triphenylamine-based dendrimers: single photon timing and femtosecond transient absorption spectroscopy. Photochem Photobiol Sci 2008;7:597.

[46] Içli S, İcil H. Fluorescence Quantum Yields of Perylene 3,4,9,10-Tetracarboxylic Acidbis -N,N'-aryl(alkyl) Diimides. Spectrosc Lett 1994;27:323-32.

[47] Singh SP, Kumar CP, Sharma GD, Kurchania R, Roy MS. Synthesis of a Modified PC70BM and Its Application as an Electron Acceptor with Poly(3-hexylthiophene) as an Electron Donor for Efficient Bulk Heterojunction Solar Cells. Adv Funct Mater n.d.;22:4087-95.

[48] Huang H, Yang L, Sharma B. Recent advances in organic ternary solar cells. J Mater Chem A 2017;5:11501-17. 